\title{
Amenability of Maruca vitrata (Lepidoptera: Crambidae) to gene silencing through exogenous administration and host-delivered dsRNA in pigeonpea (Cajanus cajan L.)
}

\section{Madhurima Chatterjee}

Indian Agricultural Research Institute

Jyoti Yadav

Indian Agricultural Research Institute

Maniraj Rathinam

National Research Center on Plant Biotechnology

Kesiraju Karthik

National Research Center on Plant Biotechnology

\section{Gopal Chowdhary}

KIIT School of Biotechnology

\section{Rohini Sreevathsa}

National Research Center on Plant Biotechnology

Uma Rao ( $\square$ umarao@iari.res.in )

Indian Agricultural Research Institute https://orcid.org/0000-0002-0278-1707

\section{Research Article}

Keywords: Maruca vitrata, RNAi, Haemolymph injection, in planta validation, Pigeonpea, Host-delivered RNAi

Posted Date: September 21st, 2021

DOl: https://doi.org/10.21203/rs.3.rs-891451/v1

License: (c) (1) This work is licensed under a Creative Commons Attribution 4.0 International License. Read Full License

Version of Record: A version of this preprint was published at Physiology and Molecular Biology of Plants on February 2nd, 2022. See the published version at https://doi.org/10.1007/s12298-022-01133-3. 


\section{Abstract}

Insect pests are one of the major biotic stresses limiting yield in commercially important food crops. The lepidopteran polyphagous spotted pod borer, Maruca vitrata causes significant economic losses in legumes including pigeonpea. RNAi-based gene silencing has emerged as one of the potential biotechnological tools for crop improvement. We report in this paper, RNAi in M. vitrata through exogenous administration of dsRNA encoding three functionally important genes, Alpha-amylase ( $a$ amylase), Chymotrypsin-like serine protease (CTLP) and Tropomyosin (TPM) into the larval haemolymph and their host-delivered RNAi in pigeonpea. Significant decline in the expression of selected genes supported by over-expression of DICER and generation of siRNA indicated the occurrence of RNAi in the dsRNA-injected larvae. Additionally, the onset of RNAi in the herbivore was demonstrated in pigeonpea, one of the prominent hosts, by host-delivered RNAi. Transgenics in pigeonpea (cv. Pusa992), a highly recalcitrant crop, were developed through a shoot apical meristem-targeted in planta transformation strategy and evaluated. Plant level bioassays in transgenic events characterized and selected at molecular level showed mortality of $M$. vitrata larvae as well as reduced feeding when compared to wild type. Furthermore, molecular evidences for down regulation of target genes in the insects that fed on transgenics authenticated RNAi. Considering the variability of gene silencing in lepidopteran pests, this study provided corroborative proof for the possibility of gene silencing in M. vitrata through both the strategies.

\section{Introduction}

Crop improvement is the foremost prerequisite for alleviation of environmental stresses and meeting food demand of the escalating population. Further, significant percentage of population, particularly in India suffers from protein deficiency due to the primary dependency on plant proteins. Pulses, the key source of dietary proteins are bogged down by several stresses, one of the major being insect pests that cause about $18-20 \%$ annual yield losses (Saxena et al. 2020). The lepidopteran legume pod borer, Maruca vitrata is known to cause serious damage to various leguminous crops (Sujayanand et al. 2021). Pigeonpea (Cajanus cajan), an important legume crop and a source of dietary protein, experiences approximately $51 \%$ yield losses annually due to $M$. vitrata (Mahalle and Taggar, 2018). The herbivore feeds on various plant parts during different stages of its life cycle. Due to the lack of resistance sources, management of this voracious herbivore is vital for pigeonpea improvement. Therefore, designing novel strategies for pest management is imperative for improvisation of the existing plant protection approaches. Sequence-specific gene silencing via RNA interference (RNAi) is a promising biotechnological approach to knock down specific gene targets affecting the insect biology, thereby reducing the severity of plant damage and curtailing yield losses.

In insect pests, RNAi has been demonstrated by both exogenous administration of gene specific dsRNA directly into the haemolymph or through artificial diet used for insect rearing besides host delivered RNAi (Christiaens et al. 2020). The efficiency of RNAi is highly variable across insect species as well as individual insects and is dependent on functionality, expression level of target genes, dosage and mode 
of double stranded (dsRNA) delivery (Whyard et al. 2009; Scott et al. 2013; Ulrich et al. 2015; Xu et al. 2016). Despite the usage of effective dsRNA delivery strategies such as microinjection and oral delivery (Vogel et al. 2019), members of lepidoptera, diptera and hemiptera exhibit less efficient response towards RNAi than coleopterans possibly due to inefficient uptake, processing and degradation of dsRNA (Cooper et al. 2019; Guan et al. 2018). In recent years, RNAi is being successfully exploited in crop improvement programmes and plant-mediated dsRNA delivery or host-delivered RNAi has proven to be a potential pest management strategy in various crops (Chung et al. 2021).

Development of transgenic plants has always been challenging in pigeonpea (Cajanus cajan L.) as recalcitrance to regeneration is the bottleneck. This setback has resulted in the reduced exploitation of biotechnological approaches for any aspect of its improvement, despite the urgent need. Addressing this limitation, non-tissue culture-based strategies have emerged as effective alternatives (Rao et al. 2008) in such recalcitrant crops. In this direction, our group has developed a shoot apical meristem-targeted in planta transformation in pigeonpea and demonstrated its feasibility in the development of stable transformants (Singh et al. 2018). The methodology has been utilized in the introgression of genes for the improvement of various agronomic traits.

Likewise, recently, our group demonstrated the possibility of RNAi through exogenous administration of gene-specific dsRNA into M. vitrata (Chatterjee et al. 2021). In continuation, the present study has been designed to explore the silencing of pertinent metabolism, growth and development-related genes of $M$. vitrata viz., Alpha-amylase (a-amylase), Chymotrypsin-like serine protease (CTLP) and Tropomyosin (TPM). These genes were chosen as targets for gene silencing using the optimized exogenous dsRNA administration into the insect haemolymph (Chatterjee et al. 2021). Further, plant level target gene perturbation was also assessed in pigeonpea transgenics developed through an in planta transformation protocol. The results thus demonstrated the possibility of RNAi in Maruca vitrata.

\section{Materials And Methods}

\section{Insect collection}

Larval stages of $M$. vitrata were collected from pigeonpea fields at ICAR-Indian Agricultural Research Institute, New Delhi and their identity was confirmed by morphological characterization(Shinde et al. 2017) and use of molecular markers (Chatterjee et al. 2019). Healthy second to fifth instar larvae were separated and a few fifth instar larvae were allowed to pupate and develop into adults (Fig.1a). All the necessary stages were snap-chilled and stored at $-80^{\circ} \mathrm{C}$ until further use.

\section{Selection of target genes and bioinformatic analyses}

In this study, target genes, a-amylase, CTLP and TPM were identified from the transcriptome data of an Indian population of $M$. vitrata (unpublished).Functional domains and motifs of these genes were identified using NCBI CDD database (https://www.ncbi.nlm.nih.gov/cdd/) and Expasy PROSITE tool (https://prosite.expasy.org/) respectively (Table S1). Lepidoptera-specific FASTA sequences were aligned 
with default parameters in ClustalW algorithm for phylogenetic analysis of the selected genes (Jeanmougin et al. 1998). MEGAX software application package(Kumar et al. 2018) was used to construct phylogenetic trees of the three genes using the maximum likelihood method considering 1000 bootstrap replications under various distance models (Nei and Kumar 2000; Tamura and Nei 1993; Hasegawa et al. 1985). The sequences were queried in dsCheck to scrutinize any chances of off-target effects of the selected genes (Naito et al. 2005). Further, the sequences were subjected to blastn suite of NCBI database (https://blast.ncbi.nlm.nih.gov/) for megablast analysis to confirm sequence dissimilarity of target genes with the genomes of human, plants, beneficial insects and other organisms.

\section{PCR amplification, cloning and sequencing of target genes}

Total RNA was extracted from a single healthy late third instar $M$. vitrata larva using TRIzol ${ }^{\mathrm{TM}}$ reagent (Thermo Fisher Scientific, Waltham, USA) with minor modifications. RNA samples were analysed by Nanodrop ${ }^{\circledR} 2000$ (Thermo Fisher Scientific, Waltham, USA) and visualized on a $1.2 \%$ agarose gel. cDNA was synthesized using SuperScript ${ }^{\mathrm{TM}}$ VILO $^{\mathrm{TM}}$ (Invitrogen, USA) and amplification of target genes was carried out using gene-specific primers (Table S2). Reactions were carried out following the standardized PCR programme (Chatterjee et al. 2021) and products were visualized on a 1.5\% agarose gel. Individual PCR products were cloned into pGEM-T easy vector (Promega, Madison, WI, USA), sequenced (Agri Genome Labs Pvt. Ltd., Kochi, Kerala, India), analyzed and submitted to GenBank to obtain accession numbers.

\section{Expression analyses of target genes in different developmental stages of $M$. vitrata}

Transcript accumulation of selected genes in six distinct developmental stages (second, third, fourth, fifth instar larvae, pupa and adult) was quantified using qRT-PCR. Total RNA was isolated from three biological replicates of each developmental stage following the previously mentioned procedure. SYBR green master mix and gene specific primers (Table S2) were used to perform qRT-PCR (BioRad CFX 96 TM Real-Time System, C1000 Touch $^{\mathrm{TM}}$ Thermal cycler; Chatterjee et al. 2021) maintaining three technical replicates for each biological replicate. Translation Elongation Factor-1 a (tef-1a) was used as an internal control gene to evaluate the relative expression (Chatterjee et al. 2021). One tailed t-test was performed to calculate the mean of $C_{t}$ values $(n=3)$.

\section{dsRNA synthesis and delivery into $M$. vitrata}

Sense and antisense strands were synthesized using MEGAscript ${ }^{\mathrm{TM}}$ (Invitrogen) SP6 and T7 in vitro transcription kits utilizing pGEM-T recombinants of selected genes. Approximately $1 \mu \mathrm{g}$ of gene-specific dsRNA was later injected into the late third instar larval haemolymph (Chatterjee et al. 2021). Each genespecific dsRNA was introduced into 16 individual healthy larvae. Nuclease free water and ds-gfp (Green fluorescent protein) were injected into the same number of larvae as negative and unrelated control respectively. Observations were recorded after 24 and $48 \mathrm{~h}$ and live larvae were collected, snap chilled and stored at $-80^{\circ} \mathrm{C}$. 


\section{Evaluation of RNAi in dsRNA-injected $M$. vitrata}

\section{Quantification of relative target gene expression}

Relative gene expression of target genes and DICER in dsRNA-injected larvae was estimated by qRT-PCR analyses using normalized expression of the internal control gene, tef-1a.Comparative $C_{t}$ method (Schmittgen and Livak 2008) was applied to calculate the fold-change in the expression of target genes and presented as $\log _{2}$ - transformed values. One tailed t-tests were performed for statistical analyses of the obtained $C_{t}$ values and the mean of $C_{t}$ values of biological replicates $(n=3)$ for each treatment was calculated.

\section{Detection of siRNA in M. vitrata larvae}

Northern blot hybridization was performed to assess successful processing of dsRNA into siRNA in $M$. vitrata. For this, siRNA was isolated from larvae injected with gene specific dsRNA, ds-gfp and nuclease free water - in three replications using NucleoSpin ${ }^{\circledR}$ MiRNA isolation kit (Macherey-Nagel, Düren, Germany). Gene-specific probes for hybridization were prepared using digoxigenin labelling kit (Roche, Basel, Switzerland). Blotting and hybridization were performed as per the standardized protocol (Chatterjee et al. 2021).

\section{Host-delivered RNAi in $M$. vitrata}

\section{Development of RNAi constructs}

Hairpin RNA (hp-RNA) gene constructs were prepared to explore host-induced gene silencing effect on $M$. vitrata. The RNAi Gateway vector pK7GWIWG2 (II) was procured from VIB-UGent Center for Plant Systems Biology, Ghent, Belgium. Desired amplicons of a-amylase, CTLP and TPM were amplified from the corresponding recombinant PGEM-T clones using gene-specific gateway primers (Table S3) and subcloned into the entry vector pDONR 221. Subsequently, the gene fragments were cloned into the destination vector PK7GWIWG2(II) using LR recombination in sense and antisense orientation using Gateway recombination cloning kit (Invitrogen, United States). The recombinants containing the hp-RNA construct were transferred into E. coli ( $\mathrm{DH} 5 \mathrm{a})$ cells and selected by colony PCR using four different primer sets (gene specific forward and reverse, $n p t / /$ forward and reverse, CaMV 35 S promoter forward and right border reverse, CaMV 35 S terminator forward and reverse) (Table S3) and sequenced. Positive clones were further mobilized into Agrobacterium tumefaciens strain EHA105 by electroporation, confirmed by colony PCR and subsequently used for host-delivered RNAi in pigeonpea.

\section{In planta transformation of pigeonpea and identification of putative transformants}

Primary transformants of pigeonpea (cv. Pusa 992) were obtained following a shoot apical meristemtargeted in planta transformation (Rao et al. 2008). Approximately 100 seedlings for each gene construct were subjected to infection process and allowed to grow under greenhouse conditions. Subsequently, $\mathrm{T}_{1}$ 
seeds were harvested and screened under kanamycin pressure $(70 \mathrm{ppm})$ for the identification of putative transformants (Singh et al. 2018).

\section{Molecular characterization of putative transformants}

\section{Genomic DNA isolation and PCR analyses}

Genomic DNA was isolated from young leaves of $T_{1}$ and $T_{2}$ generation transgenic and wild type pigeonpea plants. PCR was performed to confirm the presence of transgenes using the respective genespecific (Table S1) and npt/l primers (Table S3) using standardized conditions. The presence of CTLP in both $T_{1}$ and $T_{2}$ generation plants was confirmed by gene-specific forward and reverse primers designed for Gateway cloning (Table S3). DNA extracted from wild type plant served as a negative control, RNAi vector PK7GW1WG2 (II) carrying the corresponding gene segments was used as positive control while the reaction mix without DNA was as the negative control. PCR analyses were carried out with denaturation at $94^{\circ} \mathrm{C}$ for $1 \mathrm{~min}$, annealing at $58^{\circ} \mathrm{C}$ (to amplify $\left.n p t / l\right)$ and $60^{\circ} \mathrm{C}$ (to amplify transgenes) for $1 \mathrm{~min}$ and extension at $72^{\circ} \mathrm{C}$ for $1 \mathrm{~min}$ for 35 cycles followed by final extension at $72^{\circ} \mathrm{C}$ for $10 \mathrm{~min}$. The PCR products were visualized on $1.2 \%$ agarose gel.

\section{Genomic Southern analyses}

T-DNA integration into pigeonpea genome and its copy number were analysed by Southern hybridization with gene-specific probes. Purified genomic DNA $(40 \mu \mathrm{g})$ from $\mathrm{T}_{2}$ generation transgenics of selected events and wild type plants was digested with HindIII (20U/ul) (NEB high fidelity, NEB) by overnight incubation ( $16 \mathrm{~h}$ ) at $37^{\circ} \mathrm{C}$ in a water bath. The digested DNA samples were resolved on a $0.8 \%$ agarose gel and processed as per manufacturer's (Roche, Switzerland) instructions.

\section{Detection of siRNA in transgenic pigeonpea events}

Presence of siRNA in the Southern positive $\mathrm{T}_{2}$ generation transgenic events was confirmed by northern blot hybridization using gene-specific probes. Small RNA was isolated from young leaves of selected events of transgenic pigeonpea as well as wild type plants and processed as described earlier (Hada et al. 2020).

\section{Expression analysis of pigeonpea transformants}

Total RNA was isolated from tender leaves of selected transgenic events from $\mathrm{T}_{2}$ generation and wild type plants (Spectrum ${ }^{\text {TM }}$, Sigma-Aldrich). Transcript accumulation of target genes and housekeeping gene, Initiation factor $4 a$ (IF4a), for normalizing the data was quantified by qRT-PCR analyses using respective gene-specific primers (Table S2) (Singh et al. 2018). The data was statistically validated by one tailed t-test $(n=3)$.

In planta validation of host-delivered RNAi in $\mathrm{T}_{2}$ generation transgenic pigeonpea 
$\mathrm{T}_{2}$ generation transgenic plants expressing hp-RNA constructs of a-amylase, CTLP, TPM were assessed against $M$. vitrata challenge along with the wild type plants. The experiment was set up under greenhouse conditions and $110 \mathrm{~mm}$ Petriplates were used to set up an enclosure to mimic natural conditions (Rathinam et al. 2019). The lid of the plate was replaced with a mesh and edges of the plate were sealed with sponge. Pigeonpea twigs with flower buds and flowers were placed inside each plate onto which three third instar larvae were released. Observations were recorded after every $24 \mathrm{~h}$ and at the end of eight days, the plates were removed, live pupae moulted from the released larvae were collected and stored at $-80^{\circ} \mathrm{C}$ for molecular analysis.

\section{Relative target gene expression analysis in pupae collected from transgenic events}

Total RNA was isolated from live pupae collected from the bioassay using TRIzol reagent (Thermo Fisher Scientific, Waltham, USA) and CDNA was synthesised as mentioned above. qRT-PCR was performed with gene-specific primers and housekeeping gene tef-1a was used to normalize the data. For statistical analysis, one-tailed t-test was performed $(n=3)$.

\section{Results}

\section{Bioinformatic analyses of target genes}

Initially, sequence authentication of the three selected genes was performed by NCBI Blast analysis. Domain analysis revealed that $a$-amylase, CTLP and TPM belonged to AmyAc-family (Alpha-amylase catalytic domain family), Tryp-Spc (Trypsin-like serine protease) and Tropomyosin super family respectively (Table S1). However, no significant hits were obtained in the motif analyses of the selected genes. Further, multiple sequence alignment and phylogenetic analysis with somewhat similar sequences confirmed that the sequences were conserved in different lepidopteran species. The search for off-target sites using dsCheck analysis tool (Naito et al. 2005) specifying Drosophila melanogaster as subject organism did not reveal any potential hits. Further, Megablast analysis of a-amylase, CTLP and TPM revealed $75 \%$ similarity with lepidopteran insects Atethmia centrago and Cosmia trapezina; $78 \%$ similarity with Ostrinia furnacalis and 0 . nubilalis; $92 \%$ similarity with 0 . furnacalis and Spodoptera frugiperda respectively. The analyses did not show any homologous sequence hits with the genomes of humans, plants, beneficial insects and other organisms.

Presence of the selected genes in M. vitrata was confirmed by PCR using gene-specific primers (Fig. 1b) and the amplified products were cloned, sequenced and accession numbers were obtained from NCBI (Table S1). Further, blast analyses confirmed the sequence authenticity of the selected genes.

\section{Profiling of target genes in developmental stages of M. vitrata}

Expression of the selected genes in developmental stages was analyzed by qRT-PCR (Fig. 1c). Considering the expression level of all the three genes in second instar larvae as a reference, it was found that, third instar larvae showed increased expression of TPM and CTLP and decreased expression of $a-$ 
amylase. Further, increased expression of all the three genes was observed in fourth and fifth instar larval stages. Interestingly, reduced accumulation of a-amylase and CTLP and increased expression of TPM was observed in the pupal stage. In adults, reduced transcript accumulation of all the three genes was observed.

\section{Assessment Of Rnai In Dsrna-injected Larvae}

While behavioural changes such as inactiveness and lack of feeding were observed in the dsRNA-injected larvae $24 \mathrm{~h}$ after injection (Supplementary file), nuclease free water and ds-gfp injected larvae were found to be healthy and active even after $48 \mathrm{~h}$ (Fig. 2a). Additionally, mortality was observed in ds-CTLP and dsTPM injected larvae $48 \mathrm{~h}$ after injection (Fig. 2a).

\section{Relative target gene expression analyses and siRNA production in dsRNA-injected larvae}

Expression analysis of the respective target genes in dsRNA administered Maruca larvae using qRT-PCR, injection of ds- $a$-amylase, ds-CTLP and ds-TPM resulted in a significant ( $P \leq 0.05) 2.73,5.17$ and 4.29 fold decline respectively in the transcript accumulation compared to ds-gfp-injected larvae (Fig. $2 \mathrm{~b}$ ). The down regulation of target genes was further substantiated by the increased expression of DICER though at varying levels in the ds-RNA-injected larvae (Fig. 2c). However, no expression was detected in nuclease free water and ds-gfp injected larvae. Additional proof for the presence of RNAi in the insect was established by the detection of siRNA in ds-CTLP injected $M$. vitrata larvae (Fig. 2d)

Development and identification of pigeonpea transformants harbouring hp-RNAi gene constructs

Primary transformants of pigeonpea (cv. Pusa992) carrying hp-RNA constructs (Fig. 3a) of the three M. vitrata-specific target genes were developed using a shoot apical meristem-targeted $A$. tumefaciensmediated in planta transformation strategy (Kesiraju and Sreevathsa, 2017) (Fig. 3b). The infection was carried out in 100 seedlings and 70 healthy seedlings for each gene were maintained in soilrite under greenhouse conditions. Of them, 50,55 and 60 healthy primary transformants $\left(T_{0}\right)$ carrying hairpin constructs of $a$-amylase, CTLP and TPM respectively could be revived and established. Since primary transformants $\left(T_{0}\right)$ obtained through in planta transformation are chimeras, $T_{1}$ generation plants were subjected to kanamycin screening for the identification of putative transformants (Shivakumara et al. 2017). Based on kanamycin screening, 30,35 and 38 putative $T_{1}$ generation plants harbouring $a$ amylase, CTLP and TPM respectively could survive and grow under greenhouse conditions (Fig. 4a). Of those, 25, 30 and 28 plants of $a$-amylase, CTLP and TPM respectively with good vegetative growth were selected for further molecular characterization.

Molecular characterization of pigeonpea transgenics for T-DNA integration and expression PCR analysis 
PCR analyses of selected $\mathrm{T}_{1}$ generation putative transgenics carrying a-amylase, CTLP and TPM demonstrated amplification of the desired fragments in 16, 22 and 13 plants (Fig. 4b) and absence in wild type plants (Fig. 4b). Based on the growth and survival of the PCR positive plants, 7 events for $a$ amylase $(1-3,1-4,9-12,12-3,24-1,24-3,24-4), 6$ events each for $\operatorname{CTLP}(1-5,2-3,2-5,3-6,4-1$, $15-3)$ and $\operatorname{TPM}(1-3,12-1,15-2,15-3,15-4,15-7)$ were maintained in the green house and advanced to $T_{2}$ generation for further analysis.

In $T_{2}$ generation, 10 plants from each of the selected events were randomly selected and subjected to PCR analysis using gene specific (Table S2) and nptIl-specific primers (Table S3). Amplification of the desired amplicons in the selected plants of $T_{2}$ progeny indicated the inheritance of T-DNA (Fig. 5a). Further, PCR amplification followed by chi-square analysis (Table S4) demonstrated the segregation of TDNA in 3:1 ratio in the $T_{2}$ generation plants.

\section{Genomic Southern analysis and Detection of siRNA in transgenic events}

Genomic Southern analysis of representative PCR positive $\mathrm{T}_{2}$ generation pigeonpea events showed that the hybridization pattern varied across the selected events and integration in single (a-amylase $24-1$ and TPM $15-3$ ) or two copies (CTLP1-5) (Fig. 5b). However, no hybridization signal was detected in wild type. Further, production of siRNA in Southern positive pigeonpea transgenic events (24- 1 of $a$-amylase, 1-5 of CTLP and 15-3 of TPM) demonstrated the processing of dsRNA of respective target genes (Fig. 5c).

\section{Analysis of transgenic plants for transcript accumulation of target genes}

Transcript abundance was quantified by qRT-PCR in five characterized events from $\mathrm{T}_{2}$ progeny of each gene. Significant levels $(P \leq 0.05)$ of transcript accumulation were detected in all the five events of each gene in terms of average $C_{t}$ values, normalized with the expression of IF4a. No transcript could be detected in wild type plants (Fig. 5d).

In planta validation of host-delivered RNAi in $\mathrm{T}_{2}$ generation transgenic events

Plant level bioassays were performed to validate host delivered RNAi in transgenic pigeonpea (Fig. 6a). $\mathrm{T}_{2}$ progeny plants of events $1-4$ and $24-1$ carrying a-amylase, $1-5$ and $3-6$ of $C T L P, 12-1$ and $15-3$ harbouring TPM showed their effectiveness against $M$. vitrata. As $M$. vitrata larvae naturally feed on pigeonpea flowers, it was observed that, there was an increased consumption of floral parts and proportionate defecation by the larvae feeding on the wild type plants by eight days. On the other hand, the effect of gene silencing corroborating with lack of feeding was observed in transgenic events (Fig. 6b). Larval mortality was also observed after $72 \mathrm{~h}$ in two plants of a single event $(24-1)$ carrying the $a$-amylase hp-RNA (Fig. $6 \mathrm{c}$ ). At the end of 8 days, the larvae that survived on transgenic plants 
moulted into pupae. Viable $M$. vitrata pupae were collected from both transgenic and wild type plants to investigate transcriptional perturbance of target genes due to host-delivered RNAi.

\section{Assessment of target gene perturbance in M. vitrata pupae}

Relative gene expression analysis depicted one fold decrease in the transcript accumulation of $a$-amylase in pupae collected from the descendent plants of events 1-4 and 24-1 compared to pupae from wild type plants (Fig. 6d). Interestingly, upto 3.5 fold increased transcript accumulation and 3.8 fold reduction was observed in the pupae collected from descendent plants of events 1-5 and 3-6 respectively, harbouring hp-CTLP. In contrast, 5.23 and 0.6 fold increase in transcript levels were observed in pupae from representative plants of events $12-1$ and $15-3$ carrying TPM hp-RNA construct.

\section{Discussion}

Management of insect pests is imperative to address agricultural sustainability under the changing climatic conditions and mounting population. The present study deals with the demonstration of RNAi using two strategies, exogenous administration of target gene-specific dsRNA into the haemolymph of $M$. vitrata and in planta validation through host delivered RNAi in pigeonpea.

A prerequisite for the successful demonstration of RNAi in any system is the selection of target genes. In an earlier study, dsRNA administration into the haemolymph of $M$. vitrata larvae showed significant perturbation in the transcripts of target genes and increased accumulation of DICER transcripts along with certain behavioural changes indicating occurrence of RNAi (Chatterjee et al. 2021). Further, we also demonstrated that dsRNA injection in the insect haemolymph was found to be superior when compared to dsRNA droplet ingestion (Chatterjee et al. 2021). Hence, in the present investigation, we further extended this approach to evaluate the silencing effect of other functionally important genes of $M$. vitrata through exogenous dsRNA administration into the larval haemolymph.

Studies have demonstrated that development of new insecticidal strategies are generally skewed towards midgut expressed genes in the lepidopteran insects (Srinivasan et al. 2005; Chougule et al. 2008). Thus, in the present study, we selected two midgut-expressed genes, a-amylase and CTLP. a-amylase is a major enzyme involved in the digestion process, is mostly secreted in the midgut and catalyses the hydrolysis of starch and glycogen (Lage 2018). Amylases are also responsible for balancing the changeable ratios of starch in the diet to supply energy required for all the cellular functions (Valencia-Jimenez et al. 2008). Similarly, characterization of CTLP revealed their involvement in protein digestion (Zhang et al. 2010). Further, TPM, a key regulatory gene involved in the initiation of flight muscle cell contraction in insects (Iwamoto 2011) was also selected.

Target gene expression analysis in different developmental stages of $M$. vitrata supported their relevance in RNAi studies. Reduced expression of a-amylase was found in the third instar larvae while fourth and fifth instar larvae exhibited increased expression, demonstrating the requirement of larger amounts of this digestive enzyme in higher instars with increased feeding. Similarly, over-expression of CTLP was 
observed in all the developmental stages of $M$. vitrata, except pupae. Generally, numerous serine proteases such as chymotrypsin, cysteine proteases, carboxypeptidases and aminopeptidases are foremost digestive enzymes present in the midgut of lepidopteran larvae (Zhang et al. 2010). Structurally and functionally, insect midgut undergoes significant changes during metamorphosis to accomplish moulting (Yang 2016; Lemaitre 2013). The degeneration of larval intestinal tissues occurs through apoptosis and autophagy during the pupation period in lepidoptera and diptera (Franzetti et al. 2012). This could be considered as the probable reason for the reduced expression of $\alpha$-amylase and CTLP in pupal as well as adult stages.

While increased level of TPM was depicted in all the three larval stages and pupa, adults showed reduced transcript accumulation. Though larvae are the most actively feeding stages of $M$. vitrata, the feeding is stopped during pupation when they undergo resting phase. The myofilament proteins which are conserved in flight muscles are comprised of actin-activated troponin-tropomyosin complex in all the vertebrates and invertebrates (Cao and Jin 2020) An interesting study on annual life-cycle of $M$. vitrata revealed that the highest flying activity was observed during late August to mid-October (Traore et al. 2014). In our study, the collected larvae emerged into adults at the end of October-mid November. In the present experiment this seasonal behavioural change could be attributed for the reduced expression of $T P M$ in adults.

In the present study, exploration of RNAi in M. vitrata by the exogenous administration of dsRNA was found to be successful in corroboration with the earlier demonstration (Chatterjee et al. 2021). Larval mortality, obvious lack of feeding and inactiveness, reduced expression of transcripts pertaining to the target genes and over-expression of DICER assured the commencement of successful RNAi in M. vitrata. This was further supported by the detection of siRNA in ds-CTLP injected larvae.

Though the demonstration of RNAi in the larvae is an excellent proof for the amenability of this tool, it is also relevant to assess the same at plant level. Use of RNAi in crop improvement through the delivery of dsRNA by host plants has emerged as a pertinent tool globally (Chung et al. 2021). Transgenic plants introgressed with hairpin constructs for the respective target genes serve as a route for dsRNA delivery. These plants when deliberately challenged with the target organism provide evidences for the development and efficacy of RNAi. In view of the importance of mitigating M. vitrata in pigeonpea, the feasibility of RNAi by silencing of target genes demonstrated by host-delivered RNAi in transgenic pigeonpea.

Though management of insect pests, especially the legume pod borer in pigeonpea is of utmost importance, successful biotechnological strategies have been meagre (Bett et al. 2017, Singh et al. 2018, Kumar et al. 2021). Lack of resistance in the available germplasm towards the insects as well as reduced amenability of pigeonpea to regeneration and transformation are prominent reasons. Hence, the present study can be considered as a significant contribution not only towards the demonstration of RNAi in the insect but also in the development of stable transformants in pigeonpea by employing a non- 
conventional protocol. To the best of our knowledge, this is the first report presenting host-delivered RNAi in pigeonpea against any insect pest, including M. vitrata.

A shoot apical meristem-targeted in planta transformation strategy was employed to develop transformants with the respective target gene-specific hairpin constructs (Rao et al. 2008; Singh et al. 2018; Kaur et al. 2016). Stringent antibiotic selection-based identification of putative transformants (Singh et al., 2018) followed by a methodical evaluation for the integration of T-DNA and expression of target genes identified transgenic pigeonpea events. The transgenic plants harbouring the respective hairpin constructs were evaluated in the advanced $T_{2}$ generation for stable inheritance of T-DNA. This meticulous evaluation led to the identification of five events per target gene for further analysis.

The crux of the study was to demonstrate the use of RNAi in crop improvement programmes to mitigate pests as notorious as $M$. vitrata. The major emphasis behind the development of transgenic pigeonpea was the in planta validation of the effect of gene silencing of the selected target genes against $M$. vitrata. For this, plant level bioassays were designed to mimic natural conditions (Rathinam et al. 2019) and to concomitantly capture the effect of host-delivered RNAi on the feeding $M$. vitrata larvae. Transgenic pigeonpea events with proof of T-DNA integration were challenged with $M$. vitrata larvae. Third instar larvae were used in plant level bioassays mainly because of the convenience in handling and assessment of larger sized larvae. Hence, observations on the effect of dsRNA produced by the plants could be assessed on the larvae, while molecular evidences for the onset of RNAi in the insect had to be depicted in the pupal stages. Deterrence in feeding, mortality of the larvae, down regulation of the target transcripts as well as production of siRNA in the pupae collected from the respective transgenic events evidenced successful host-mediated gene silencing. Despite the reflection of gene silencing in the downregulation of target gene-specific transcripts in pupae that were collected from the transgenic plants, upregulation of the transcripts was also observed, probably due to variation in the extent of RNAi across the challenged larvae as well as the events.

\section{Conclusion}

The study therefore demonstrated the functional importance of the selected target genes and relevance in their deployment for the control of $M$. vitrata through RNAi. The study also established the amenability of the insect to host-delivered RNAi in pigeonpea, one of the economically important recalcitrant legume crops. The information generated could pave way for the development of integrated biotechnological approaches in different crop improvement programmes to protect plants from devastating insect pests.

\section{Declarations}

\section{Acknowledgements}

We are thankful to Department of Biotechnology, Government of India (Grant No. BT/IC-2/ISCB/PhaseIV/Pigeonpea) for funding. We acknowledge Technical Officer, Mr. Purshotam Podar for helping us in 
insect collection from the field and maintenance of plants in greenhouse. We thank Dr. Pradeep Kumar Papolu for helping us during Gateway construct preparation. MC acknowledges School of Biotechnology, KIIT University, Bhubaneswar, Odisha for Ph.D registration.

\section{Statements}

\section{Compliance with ethical standards}

The authors declare that they have no conflict of interest in the publication.

\section{Availability of data and materials}

The data generated during the current study are available with the corresponding author.

\section{Authors' contribution}

UR conceived and supervised the experiments. MC and JY performed the experiments. MC, MR and KK interpreted, analysed and arranged the experimental data. RS, UR and GC reviewed and finalized the manuscript.

\section{References}

A Valencia-Jimenez, JW Arboleda, A Lopez Avila MF Grossi-de-Sa (2008) Digestive a-amylases from Tecia solanivora larvae (Lepidoptera: Gelechiidae): response to $\mathrm{pH}$, temperature and plant amylase inhibitors Bull Entomol Res 98 pp. 575-579

Bett B, Gollasch S, Moore A et al. (2017) Transgenic cowpeas (Vigna unguiculata L. Walp) expressing Bacillus thuringiensis Vip3Ba protein are protected against the Maruca pod borer (Maruca vitrata). Plant Cell Tiss Organ Cult 131: 335-345 https://doi.org/10.1007/s11240-017-1287-3

Cao T, \& Jin JP (2020) Evolution of Fight Muscle Contractility and Energetic Efficiency. Front. Physiol. 11: 1038 https://doi.org/10.3389/fphys.2020.01038

Chatterjee M, Yadav J, Vennila S, Shashank PR, Jaiswal N, Sreevathsa R, \& Rao U (2019) Diversity analysis reveals genetic homogeneity among Indian populations of legume pod borer, Maruca vitrata (F.). 3 Biotech 9(9): 1-8 https://doi.org/10.1007/s13205-019-1850-1

Chatterjee M, Yadav J, Rathinam M et al.(2021) Exogenous administration of dsRNA for the demonstration of RNAi in Maruca vitrata (lepidoptera: crambidae). 3 Biotech 11: 197 https://doi.org/10.1007/s13205-021-02741-8

Chougule NP, Doyle E, Fitches E, \& Gatehouse JA (2008) Biochemical characterization of midgut digestive proteases from Mamestra brassicae (cabbage moth; Lepidoptera: Noctuidae) and effect of soybean 
Kunitz inhibitor (SKTI) in feeding assays. J. Insect Physiol. 54(3): 563-

572 https://doi.org/10.1016/j.jinsphys.2007.12.005

Christiaens O, Niu J, \& Nji Tizi Taning C (2020) RNAi in Insects: A revolution in fundamental research and pest control applications. Insects 11(7): 415 https://doi.org/10.3390/insects11070415.

Chung SH, Feng H \& Jander G (2021) Engineering pest tolerance through plant-mediated RNA interference. Curr. Opin. Plant Biol 60: 102029 https://doi.org/10.1016/j.pbi.2021.102029

Cooper AM, Silver K, Zhang J, Park Y, \& Zhu KY (2019) Molecular mechanisms influencing efficiency of RNA interference in insects. Pest manag. sci. 75(1): 18-28 https://doi.org/10.1002/ps.5126.

Da Lage J-L (2018) The Amylases of Insects. Int. J. Insect

Sci. https://doi.org/10.1177/1179543318804783.

Franzetti E, Huang ZJ, Shi YX, Xie K, Deng XJ, Li JP, et al. (2012) Autophagy precedes apoptosis during the remodelling of silkworm larval midgut. Apoptosis 17(3): 305-324 https://doi.org/10.1007/s10495011-0675-0.

Guan RB, Li HC, Fan YJ, Hu SR, Christiaens O, Smagghe G \& Miao XX (2018) A nuclease specific to lepidopteran insects suppresses RNAi. J. Biol. Chem 293(16): 6011-6021 doi:

10.1074/jbc.RA117.001553.

Hada A, Kumari C, Phani V, Singh D, Chinnusamy V, \& Rao U (2020) Host-induced silencing of FMRF amide-like peptide genes, $f l p-1$ and $f l p-12$, in rice impairs reproductive fitness of the root-knot nematode Meloidogyne graminicola. Front. Plant Sci. 11: 894 https://doi.org/10.3389/fpls.2020.00894.

Hasegawa M, Kishino H, and Yano T (1985) Dating the human-ape split by a molecular clock of mitochondrial DNA. J. Mol. Evol. 22:160-174

Iwamoto H (2011) Structure, function and evolution of insect flight muscle. Biophysics 7: 21-28. doi: 10.2142/biophysics.7.21

Jeanmougin F, Thompson JD, Gouy M, Higgins DG, \& Gibson TJ (1998) Multiple sequence alignment with Clustal X. Trends Biochem. Sci. 23(10): 403-405 https://doi.org/10.1016/S0968-0004(98)01285-7.

Kaur A, Sharma M, Sharma C, Kaur H, Kaur N, Sharma S, et al. (2016) Pod borer resistant transgenic pigeon pea (Cajanus cajan L.) expressing cry1Ac transgene generated through simplified Agrobacterium transformation of pricked embryo axes. Plant Cell, Tissue and Organ Culture (PCTOC) 127(3): 717-727 DOI 10.1007/s11240-016-1055-9.

Kesiraju K, Sreevathsa R (2017) Apical meristem-targeted in planta transformation strategy: an overview on its utility in crop improvement. Agri. Res. and Techol. https://doi.org/10.19080/ARTOAJ.2017.08.555734 
Kumar A, Jaiwal R, Sreevathsa R et al. (2021) Transgenic cowpea plants expressing Bacillus thuringiensis Cry2Aa insecticidal protein imparts resistance to Maruca vitrata legume pod borer. Plant Cell Rep. 40:583-594https://doi.org/10.1007/s00299-020-02657-2

Kumar S, Stecher G, Li M, Knyaz C and Tamura K (2018) MEGA X: molecular evolutionary genetics analysis across computing platforms. Mol. Biol. Evol. 35: 1547-1549

https://doi.org/10.1093/molbev/msy096

Lemaitre B, \& Miguel-Aliaga I (2013) The digestive tract of Drosophila melanogaster. Ann. Rev. Genetics 47: 377-404 https://doi.org/10.1146/annurev-genet-111212-133343

Mahalle RM, Taggar GK (2017) Yield loss assessment and establishment of economic threshold level of Maruca vitrata in pigeonpea. Journal of Food Legumes 31(1):36-44

Naito Y, Yamada T, Matsumiya T, Ui-Tei K, Saigo K, Morishita S (2005) dsCheck: highly sensitive off-target search software for double-stranded RNA-mediated RNA interference. Nucleic Acids Res. Jul 1; 33 (Web Server issue), W589-91. doi: 10.1093/nar/gki419. PMID: 15980542; PMCID: PMC1160180.

Nei M and Kumar S (2000) Molecular Evolution and Phylogenetics. Oxford University Press, New York

Rathinam M, Marimuthu SK, Tyagi S, Kesiraju K, Prabha AL, Rao U, \& Sreevathsa R (2019) Characterization and in planta validation of a $\mathrm{CHI} 4$ chitinase from Cajanus platycarpus (Benth.) Maesen for its efficacy against pod borer, Helicoverpa armigera (Hübner). Pest Management Science https://doi.org/10.1002/ps.6260.

Sankara Rao K, Sreevathsa R, Sharma PD et al. (2008) In planta transformation of pigeon pea: a method to overcome recalcitrancy of the crop to regeneration in vitro. Physiol. Mol. Biol. Plants 14:321-328 https://doi.org/10.1007/s12298-008-0030-2

Saxena H, Bandi SM, Revanasidda (2020) Sucking Pests of Pulse Crops. In: Omkar (eds) Sucking Pests of Crops. Springer, Singapore https://doi.org/10.1007/978-981-15-6149-8_3

Schmittgen TD and Livak KJ (2008) Analyzing real-time PCR data by the comparative $\mathrm{C}_{\mathrm{T}}$ method. Nat. Protoc. 3: 1101-1108 https://doi.org/10.1038/nprot.2008.73

Scott JG, Michel K, Bartholomay LC, Siegfried BD, Hunter WB, Smagghe G, et al. (2013) Towards the elements of successful insect RNAi, J. Insect Physiol 59(12): 1212-1221

https://doi.org/10.1016/j.jinsphys.2013.08.014

Shinde KG, Naik KV, Raut PP, Desai VS, \& Mehendale SK (2017) Biology of Pod Borer, Maruca vitrata (Geyer) Infesting Lablab Bean. Int. J. Curr. Microbiol. App. Sci 6(9): 67-74

Shivakumara TN, Sreevathsa R, Dash PK et al. (2017) Overexpression of Pea DNA Helicase 45 (PDH45) imparts tolerance to multiple abiotic stresses in chilli (Capsicum annuum L.). Sci Rep 
Singh S, Kumar NR, Maniraj R et al. (2018) Expression of Cry2Aa, a Bacillus thuringiensis insecticidal protein in transgenic pigeon pea confers resistance to gram pod borer, Helicoverpa armigera. Sci 8:8820 https://doi.org/10.1038/s41598-018-26358-9

Srinivasan A, Chougule NP, Giri AP, Gatehouse JA, \& Gupta VS (2005) Pod borer (Helicoverpa armigera Hübn.) does not show specific adaptations in gut proteinases to dietary Cicer arietinum Kunitz proteinase inhibitor. J Insect Physiol. 51(11): 1268-1276 https://doi.org/10.1016/j.jinsphys.2005.07.005.

Sujayanand GK, Chandra A, Pandey S and Bhatt S (2021) Seasonal Abundance of Spotted Pod Borer, Maruca vitrata Fabricius in Early Pigeonpea [Cajanus cajan (L.) Millsp.] and its Management through Farm scaping in Uttar Pradesh. Legume Research: An International Journal 44(2)

Tamura K and Nei M (1993) Estimation of the number of nucleotide substitutions in the control region of mitochondrial DNA in humans and chimpanzees. Mol. Biol. Evol. 10: 512-526.

Traore F, Ba NM, Dabire-Binso CL, Sanon A, \& Pittendrigh BR (2014) Annual cycle of the legume pod borer Maruca vitrata Fabricius (Lepidoptera: Crambidae) in south-western Burkina Faso. Arthropod-Plant Interactions 8(2):155-162. https://doi.org/10.1007/s11829-014-9297-0

Ulrich J, Majumdar U, Schmitt-Engel C, Schwirz J, Schultheis D, Ströhlein N et al. (2015) Large scale RNAi screen in Tribolium reveals novel target genes for pest control and the proteasome as prime target. BMC genomics 16(1): 1-9 https://doi.org/10.1186/s12864-015-1880-y

Vogel E, Santos D, Mingels L, Verdonckt TW, \& Broeck JV (2019) RNA interference in insects: protecting beneficials and controlling pests. Front. physiol. 9: 1912 doi: 10.3389/fphys.2018.01912

Whyard S, Singh AD, \& Wong S (2009) Ingested double-stranded RNAs can act as species-specific insecticides. Insect Biochem. Mol. Biol. 39(11): 824-832 https://doi.org/10.1016/j.ibmb.2009.09.007

Xu J, Wang XF, Chen P, Liu FT, Zheng SC, Ye H, \& Mo MH (2016) RNA interference in moths: mechanisms, applications, and progress. Genes 7(10): 88 https://doi.org/10.3390/genes7100088.

Yang B, Huang W, Zhang J, Xu Q, Zhu S, Zhang Q, et al. (2016) Analysis of gene expression in the midgut of Bombyx mori during the larval molting stage. BMC genomics 17(1): 1-

16 https://doi.org/10.1186/s12864-016-3162-8.

Zhang C, Zhou D, Zheng S, Liu L, Tao S, Yang L, et al. (2010) A chymotrypsin-like serine protease cDNA involved in food protein digestion in the common cutworm, Spodoptera litura: Cloning, characterization, developmental and induced expression patterns, and localization. J. Insect Physiol. 56(7): 788-799

\section{Figures}




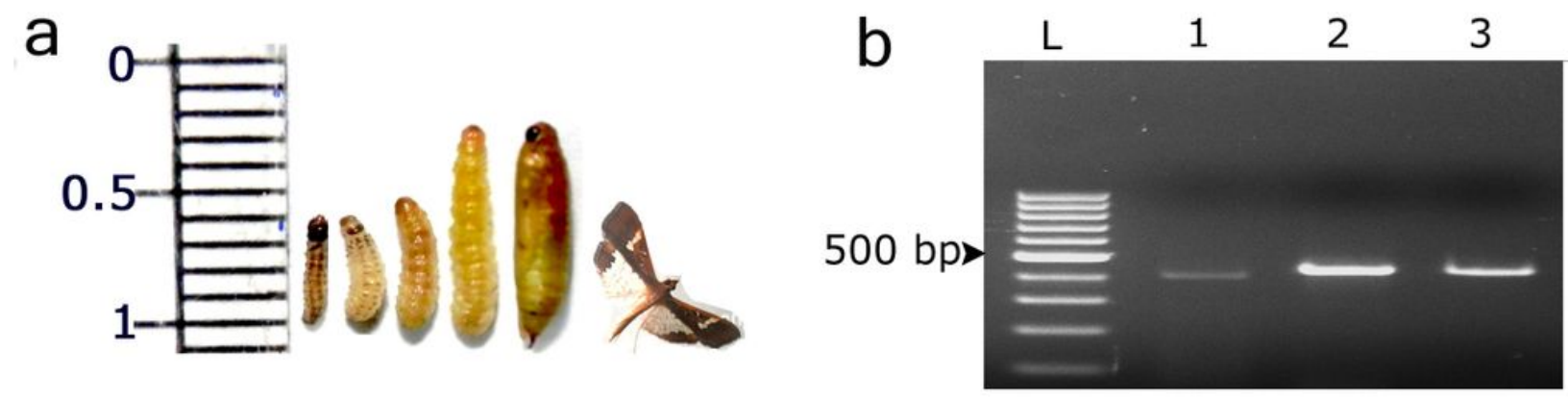

$\begin{array}{llll}\text { C } & \text { Third instar } \\ \text { Fourth instar } & \text { Fifth instar } & \text { Pupa } & \text { Adult }\end{array}$

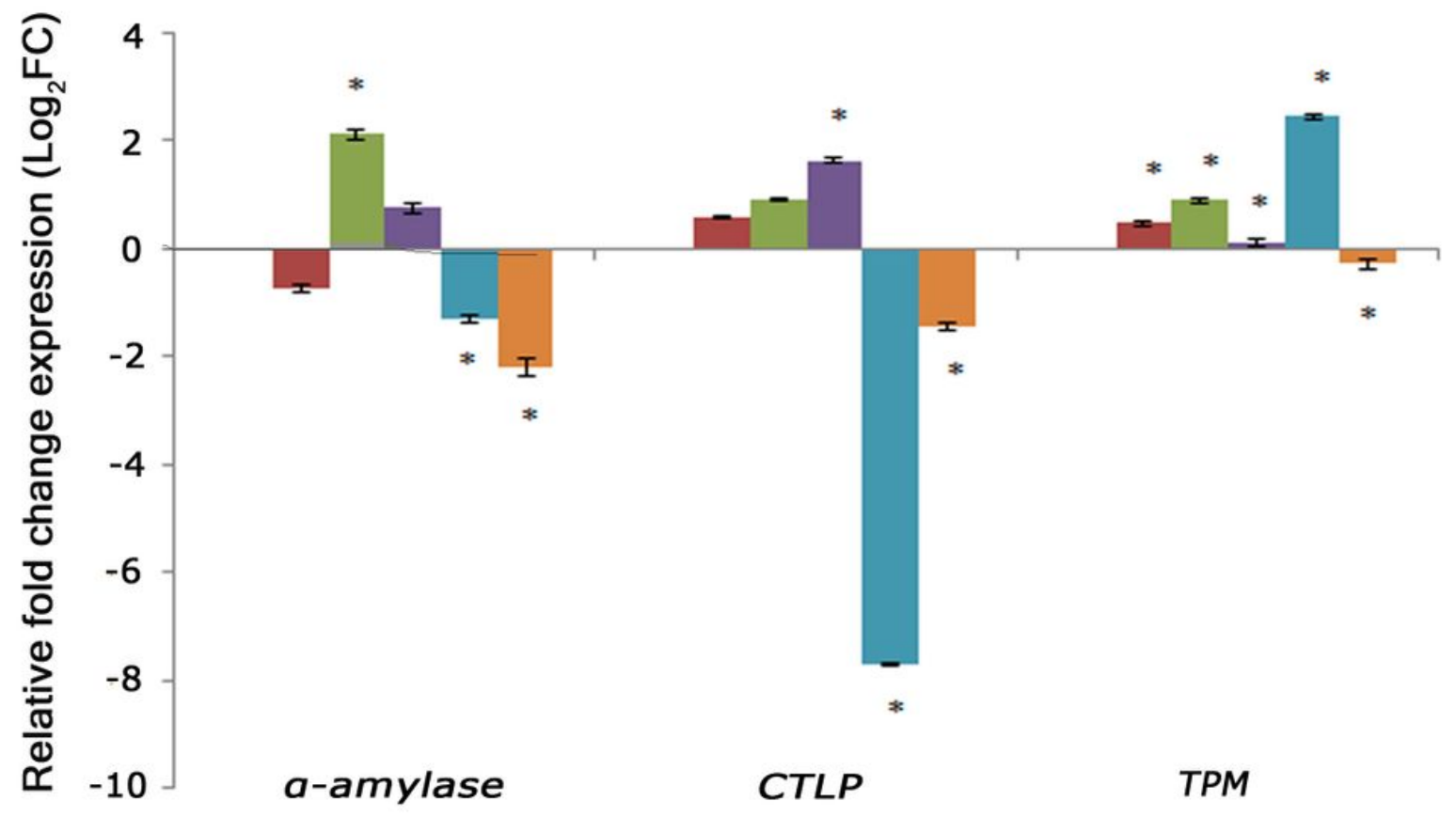

Figure 1

Expression analysis of selected genes in different developmental stages of M. vitrata. (a) Developmental stages of M. vitrata. L-R: second, third, fourth and fifth instar larva, pupa and adult. (b) PCR amplification of selected genes. Lanes L: 100 bp DNA ladder, 1-3: a-amylase (415 bp); CTLP (444 bp); TPM (442 bp). (c) Relative fold change expression analysis of selected genes by qRT-PCR in different developmental stages of M. vitrata. Each bar depicts the log2 -transformed mean \pm S.E of three biological and three 
technical replicates. Asterisks indicate statistical significance of differential expression $(P \leq 0.05)$ considering the gene expression of second instar larvae as baseline.

a
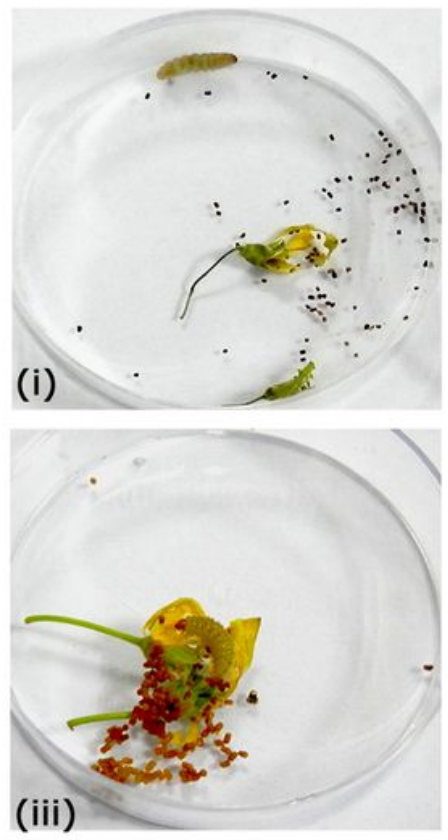

(ii)
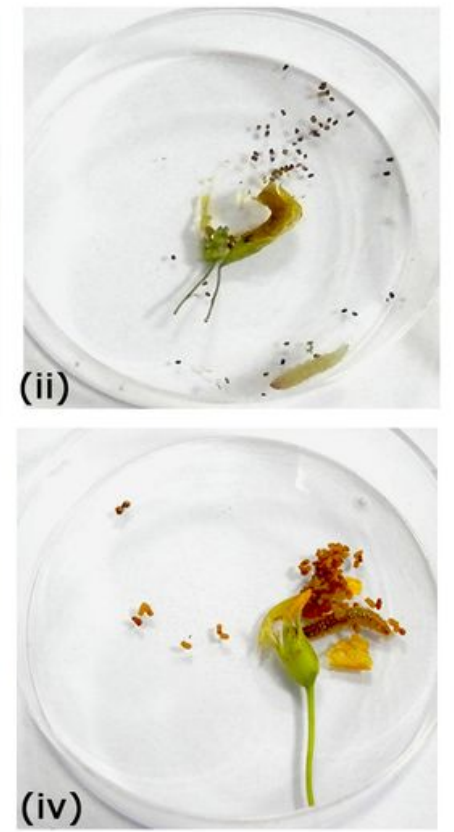

b

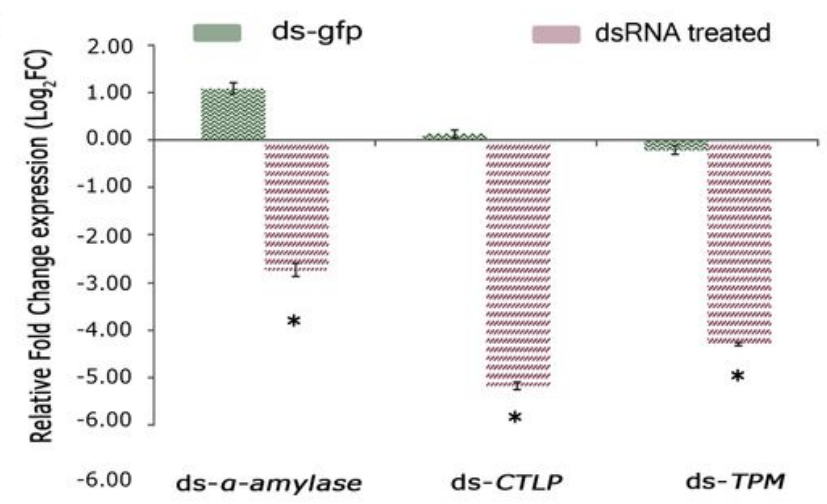

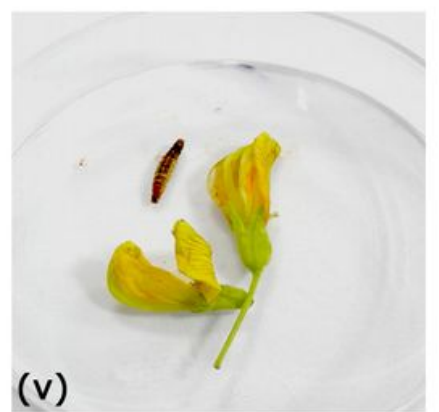
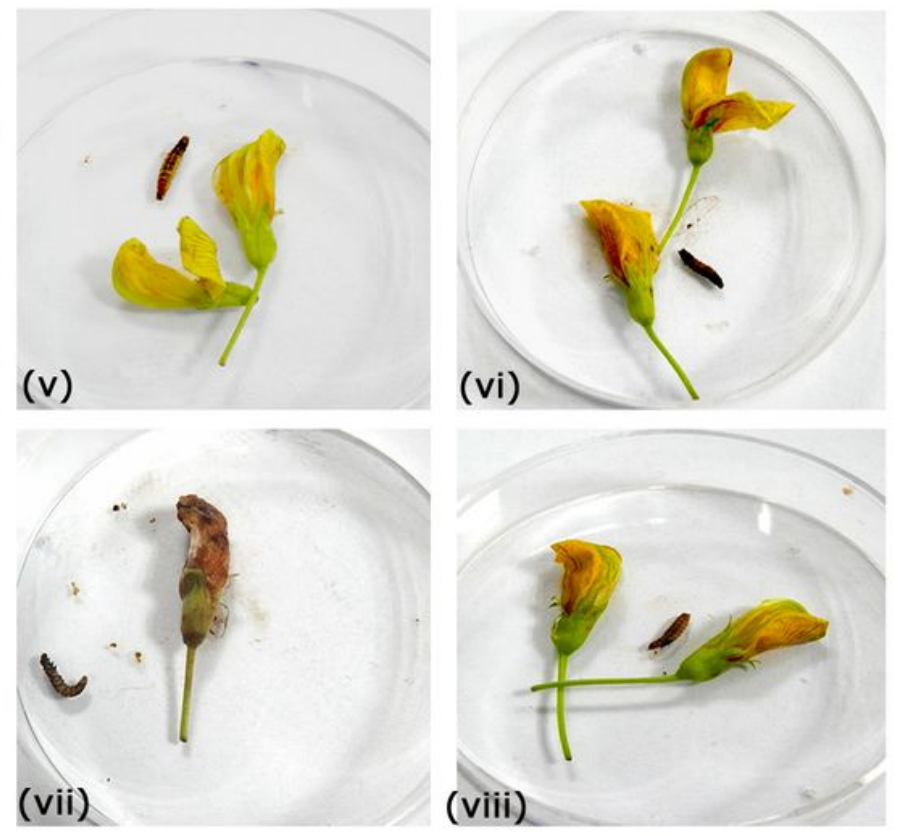

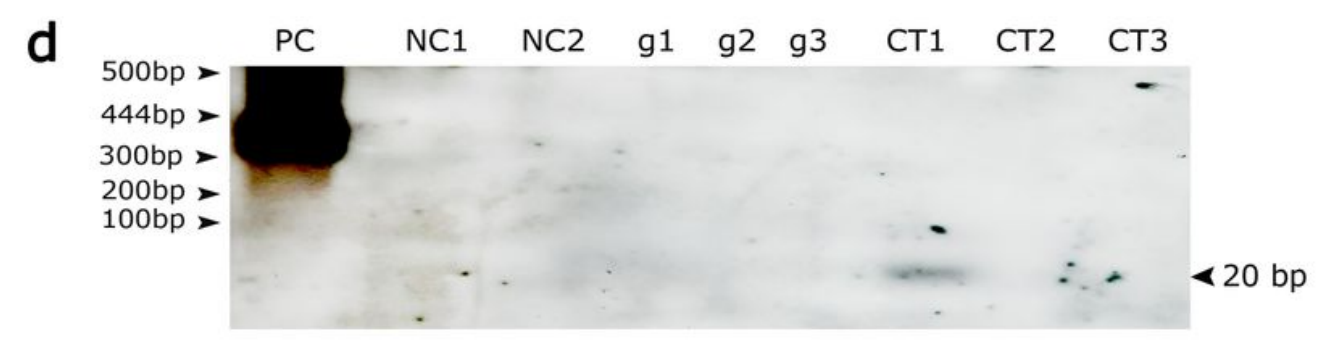

\section{Figure 2}

Assessment of RNAi in gene specific dsRNA-injected larvae. (a) (i)-(iv) Normal feeding and behaviour were observed in nuclease free water and ds-gfp injected larvae 48h after injection. (v) and (vi) Larval mortality observed in ds-CTLP injected larvae $48 \mathrm{~h}$ after injection. (vii) and (viii) Larval mortality observed in ds-TPM injected larvae $48 \mathrm{~h}$ after injection. (b) Relative gene expression analysis in ds-gfp as well as gene specific dsRNA injected larvae $48 \mathrm{~h}$ after injection. Each bar represents log 2 -transformed mean \pm S.E of three biological and three technical replicates. Asterisks indicate statistical significance of 
differential expression $(P \leq 0.05)$ in comparison with gene expression in nuclease free water injected larvae. (c) Relative gene expression analysis of DICER in dsRNA injected larvae, $48 \mathrm{~h}$ after injection. Each bar represents log2 -transformed mean \pm S.E of three biological and three technical replicates. Asterisks indicate statistical significance of differential expression $(P \leq 0.05)$ in comparison with water-injected larvae. (d) Detection of siRNA by Northern blot hybridization using gene specific probe (444bp) in dsCTLP injected larvae, $48 \mathrm{~h}$ after injection. Lanes PC: Positive Control (Gene specific probe); NC1 and NC2: Negative Control (siRNA isolated from two individual nuclease free water injected larvae); g1, g2 and g3: siRNA isolated from three individual ds-gfp injected larvae; CT1, CT2 and CT3: siRNA isolated from three individual ds-CTLP injected larvae.

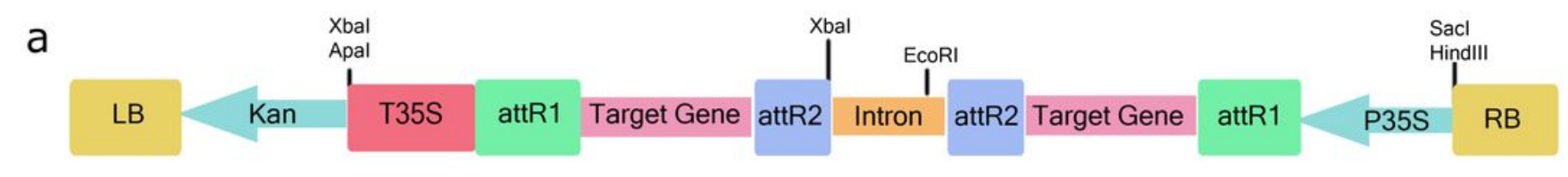

b
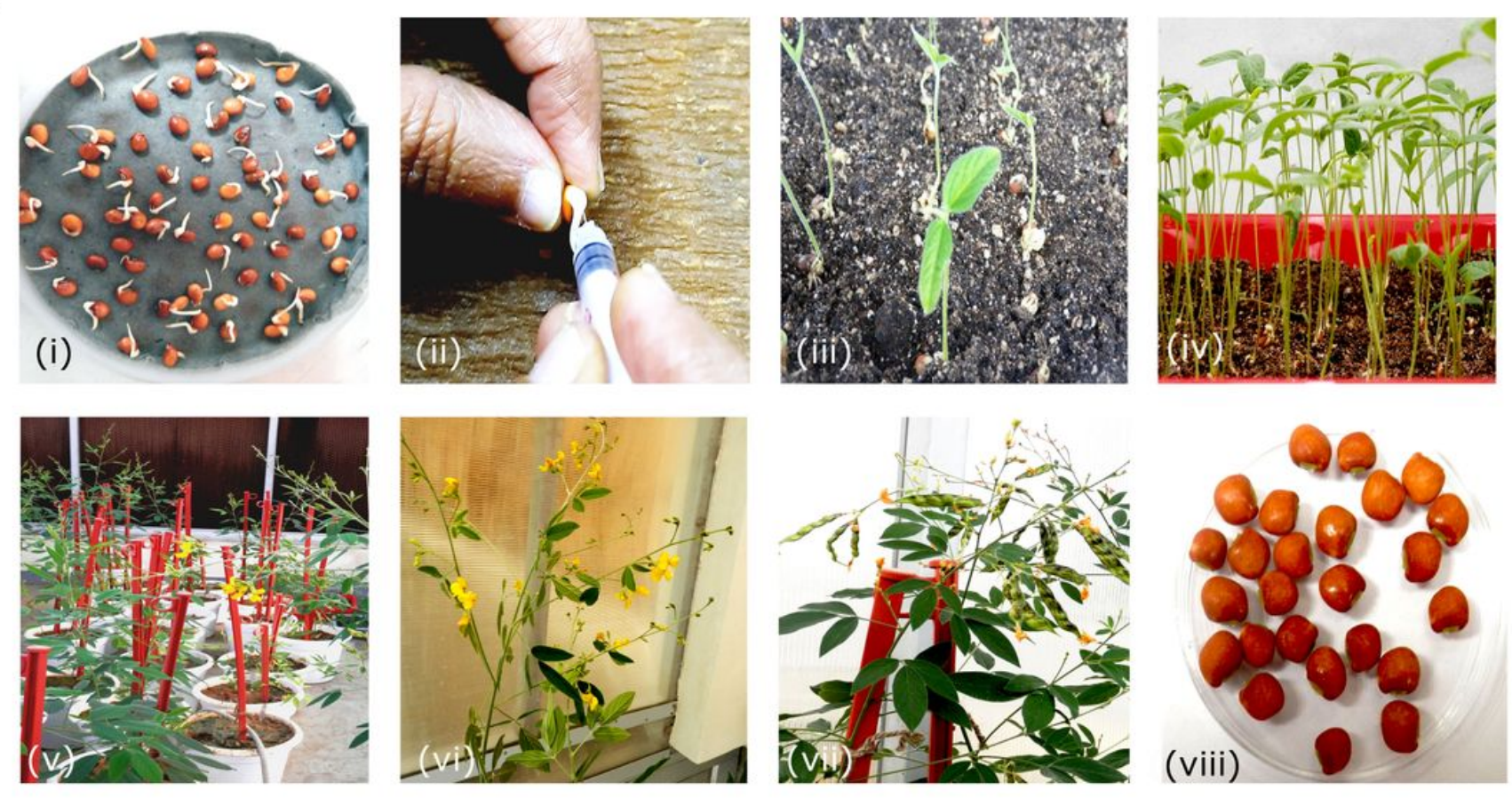

\section{Figure 3}

In planta transformation of pigeonpea (cv. Pusa 992) with hairpin-RNA (hp-RNA) constructs. (a) Schematic representation of linearized vector map of Gateway hp-RNA construct pK7GWIWG2(II). (b) (i) Germinated pigeonpea seeds used for in planta transformation. (ii) Representation of shoot apical meristem-targeted in planta transformation of pigeonpea cv. Pusa 992. (iii) - (vii) T0 generation pigeonpea transformants were allowed to establish under greenhouse conditions and set seeds. (viii) Seeds obtained from T0 generation plants of pigeonpea. 


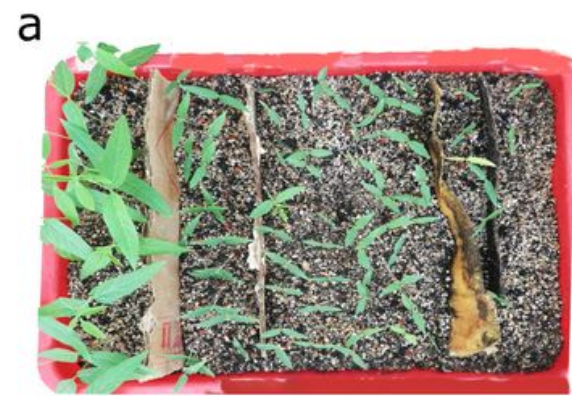

(i)

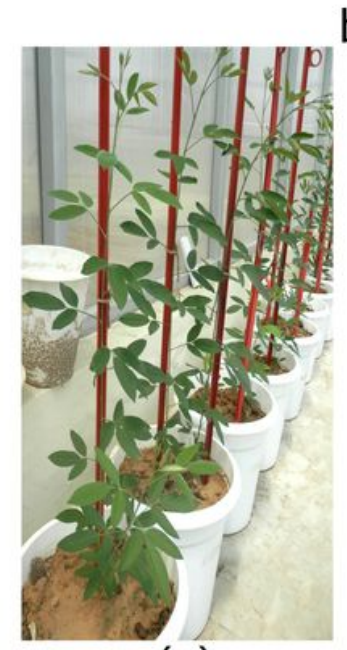

(

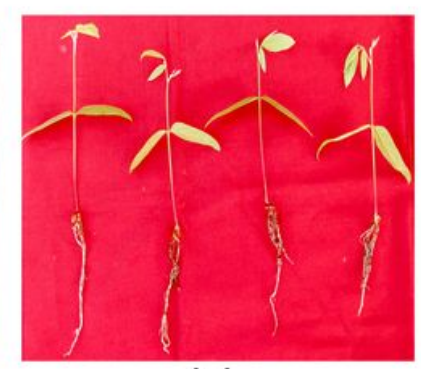

(ii)

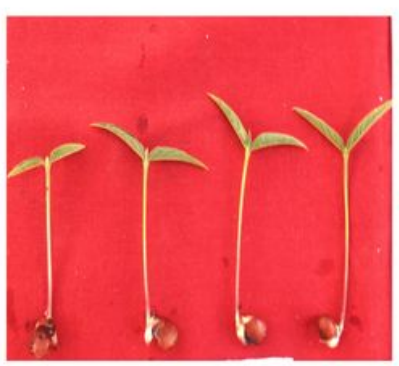

(iii)

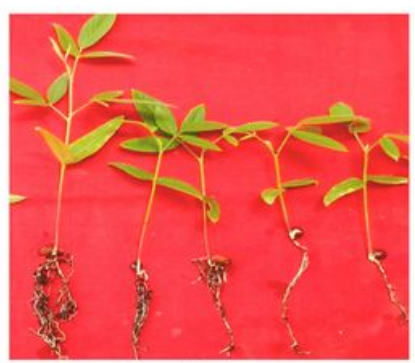

(iv)

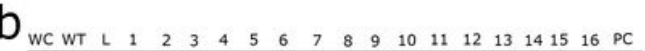
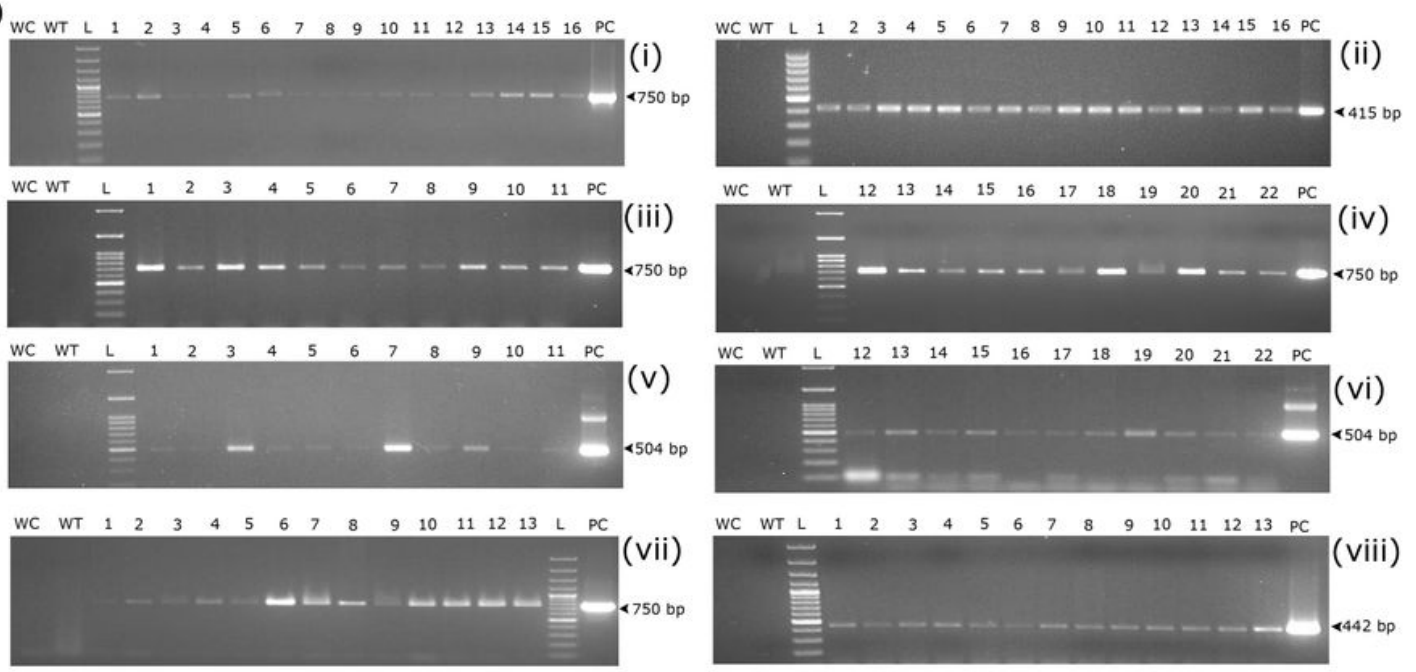

\section{Figure 4}

Assessment of T1 generation pigeonpea plants.(a) (i) Screening of T1 generation plants with $70 \mathrm{ppm}$ kanamycin to identify putative transgenics. (ii) Absolute control pigeonpea plants. (iii) Control pigeonpea plants treated with 70 ppm kanamycin. (iv) T1 generation putative pigeonpea transgenics (v) Maintenance of T1 generation putative transformants under greenhouse condition. (b) PCR analysis of T1 generation putative transgenics: Lanes L: 100 bp DNA ladder; WC: water control; WT: wild type; PC: positive control; (i) and (ii) Lanes 1-16: Amplification of nptll (750 bp) and a-amylase (415 bp) in 16 T1 generation transgenics. (iii)-(vi) Lanes 1-22: Amplification of nptll (750 bp) and CTLP (504 bp) in 22 T1 generation transgenics. (vii) and (viii) Lanes 1-13: Amplification of nptll (750 bp) and TPM (442 bp) in 13 T1 generation transgenics. 


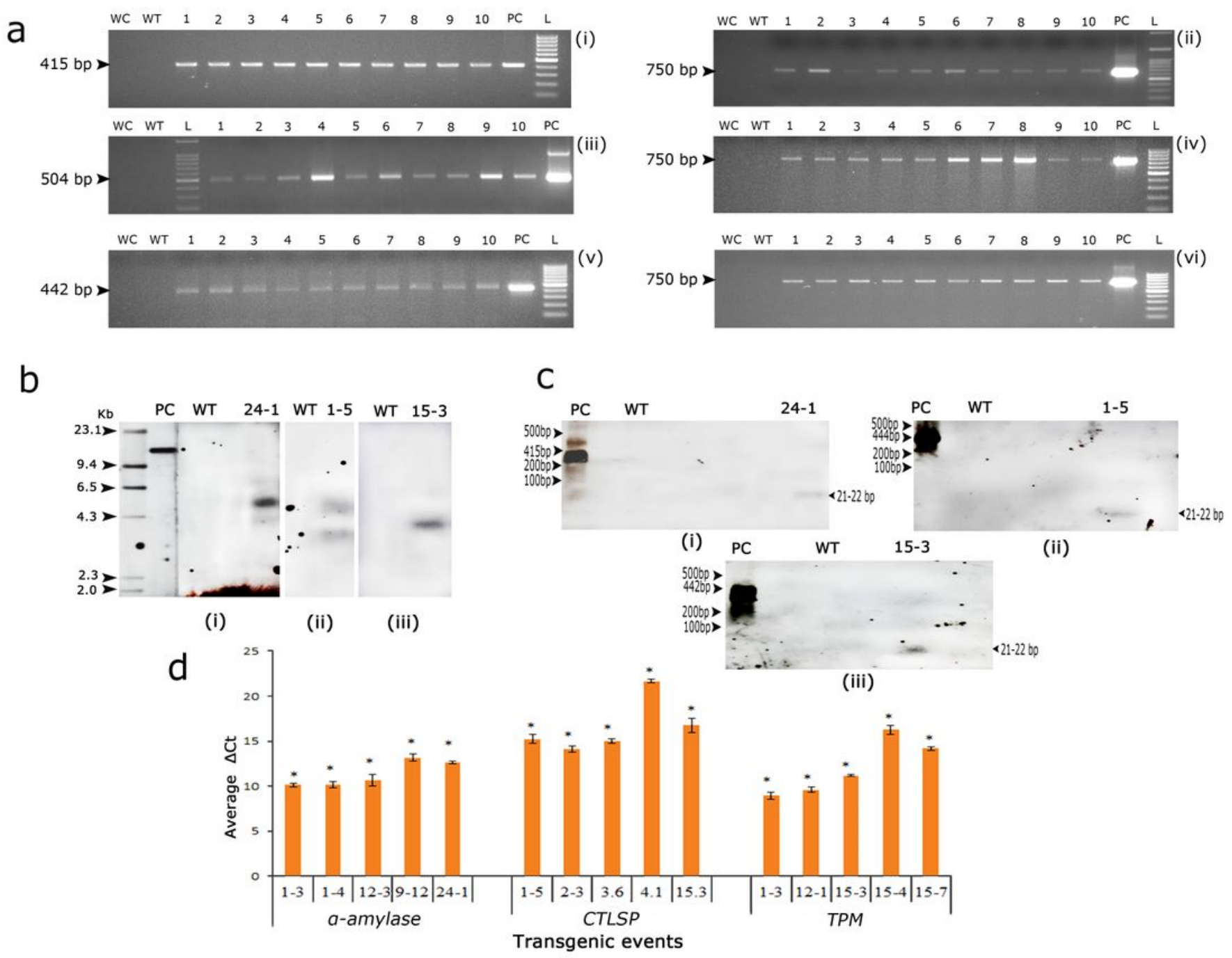

\section{Figure 5}

Molecular characterization of T2 generation transgenic pigeonpea plants. (a) PCR analysis of T2 generation transgenic plants: Lanes L: 100 bp DNA ladder; WC: water control; WT: wild type; PC: positive control. (i) and (ii) PCR amplification of a-amylase and nptll in T2 generation transgenics: Lanes 1-10: representative plants from 7 selected events (1-3, 1-4, 9-12, 12-3, 24-1, 24-3, 24-4). (iii) and (iv) PCR amplification of CTLP and nptll in T2generation transgenics: Lanes 1-10: representative plants from 6 selected events (1-5, 2-3, 2-5, 3-6, 4-1, 15-3). (v) and (vi) PCR amplification of TPM and nptll in T2 generation transgenics: Lanes 1-10: representative plants from 6 selected events (1-3, 12-1, 15-2, 15-3, 154, 15-7). (b) Genomic Southern analysis for the confirmation of stable T-DNA integration in T2 generation transgenic events. $40 \mu \mathrm{g}$ purified genomic DNA of both transgenic and wild- type pigeonpea leaves was digested with HindlII and probed with corresponding genes: Lanes PC: Linearized pK7GWIWG2 (II) plasmid (200 pg); WT: digested DNA from wild type pigeonpea. (i) DNA from event 24-1 harbouring the hp-RNA construct of transgene a-amylase. (ii) DNA from event 1-5 harbouring the hp-RNA construct of transgene CTLP. (iii) DNA from event 15-3 harbouring the hp-RNA construct of transgene TPM. (c) Northern blot hybridization for detection of siRNA production in transgenic events: Lanes PC: Gene 
specific probes; WT: siRNA isolated from wild type plant. (i) Detection of siRNA in the event 24-1 harbouring the a-amylase hp-RNA construct. (ii) Detection of siRNA in the event 1-5 harbouring the CTLP hp-RNA construct. (iii) Detection of siRNA in the event 15-3 harbouring the TPM hp-RNA construct. (d) qRT-PCR analysis for the evaluation of transcript abundance in selected five events of each gene. Expression of internal control gene, IF4a was used for normalization of $\mathrm{Ct}$ values. Each bar referred to the difference in mean $\mathrm{Ct}$ of transgene and internal control gene. Asterisks indicate the statistical significance $(P \leq 0.05)$ of $\triangle$ Ct values.

a
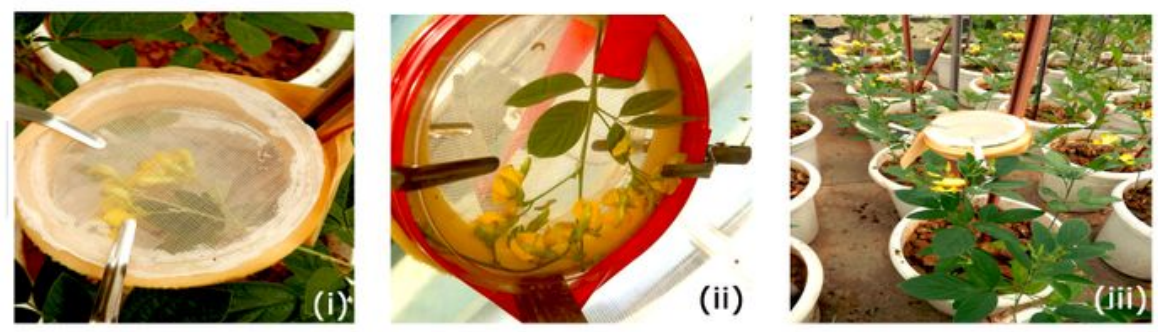

b

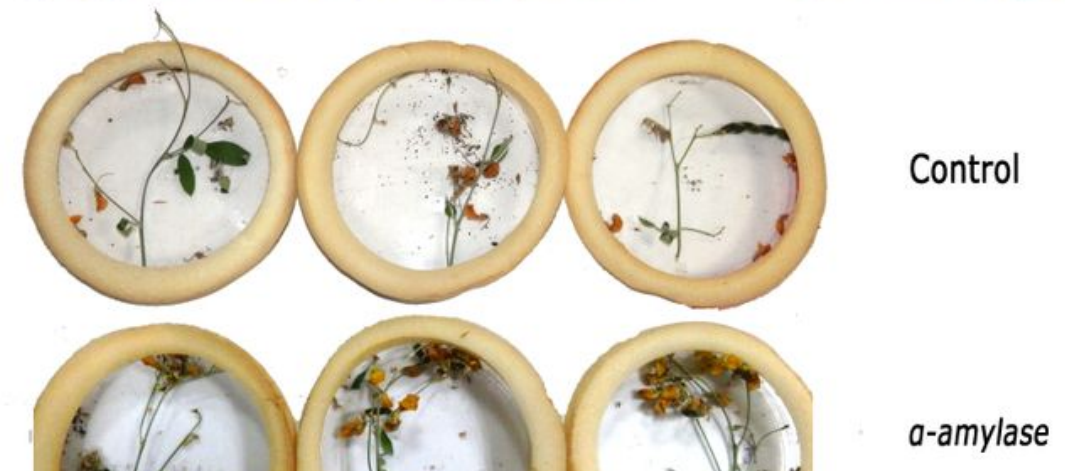

\section{CTLP}

TPM

C

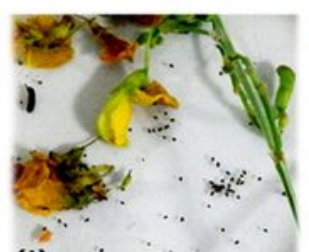

(i)

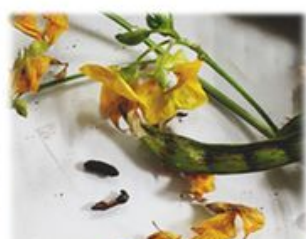

(ii) Axy, a d

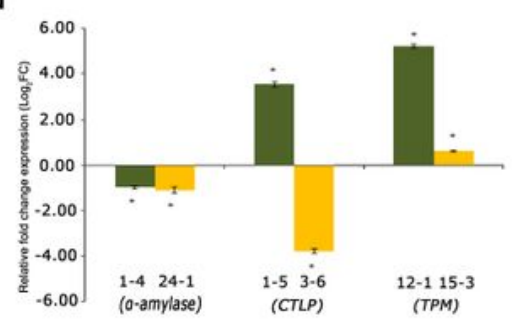




\section{Figure 6}

In planta validation of host-delivered RNAi in T2 generation pigeonpea plants.(a) (i)-(iii) Set-up used for the in planta validation of host-delivered RNAi under greenhouse conditions. Three healthy third instar larvae were released onto each plant. Two molecular analysis-confirmed events per gene were selected and three plants per event were used as biological replicates. Same set-up was used in greenhouse grown wild type plants for comparative analysis. (b) (i) Efficient feeding observed in wild type plants eight days after the experiment; (ii)-(iv) Feeding avoidance observed in transgenic plants (representative picture). (c) (i) and (ii) Larval mortality observed in two plants of event 24-1 harbouring the transgene hp-RNA construct of a-amylase $72 \mathrm{~h}$ after the experiment. (d) Relative gene expression analysis in the pupated larvae that survived on the transgenics. Each bar represents log2 -transformed mean \pm S.E of three biological and three technical replicates for each event. Asterisks indicate statistical significance of differential expression $(P \leq 0.05)$ in comparison with pupae collected from wild type plants.

\section{Supplementary Files}

This is a list of supplementary files associated with this preprint. Click to download.

- Supplementarytable.docx

- Supplementaryfile.docx 